\title{
PROTECTIVE EFFECTS OF CATECHIN ISOLATE FROM GMB4 CLONE GREEN TEA AGAINST EPC IN TYPE 2 DIABETES MELLITUS
}

\author{
Yuly Peristiowati \\ STIKes Surya Mitra Husada Kediri, East Java, Indonesia \\ Email: yulystikes@gmail.com
}

\begin{abstract}
Introduction: Type 2 diabetes mellitus is a cause of morbidity and mortality, especially due to vascular complications. This study aims to evaluate the role of catechin isolates from GMB4 clone green tea in the dynamic of endothelial progenitor cells (EPC) in type 2 diabetes mellitus (DM). Methods: 25 Wistar rats were divided into 5 groups, including a control group, type 2 diabetes mellitus group, treated daily with the administration of extract of catechin isolate from GMB4 clone green tea at 20; 40; and $60 \mathrm{mg} / \mathrm{kgBB}$ doses for 6 weeks. EPCs analysis was performed by flow cytometry, and the level of NO was analysed using a spectrophotometer, and the serum levels of SDF- $1 \alpha$ were performed with an ELISA technique. The analysis of the expression of SDF-1 and CXCR-4 was performed using immunohistochemistry techniques. Results: The CD34+ and CD133+ count was lower in the DM group compared to the control group ( $\mathrm{p}<0.05)$. Of the three doses of catechin, only the highest dose was able to significantly increase the CD34+ count compared to the rats in the diabetes mellitus group ( $\mathrm{p}<0.05)$. The serum NO level was significantly higher in the DM control group $(\mathrm{P}<0.05)$. All three doses of catechin were able to significantly increase the expression of SDF- $1 \alpha$ and CXCR4 in the aorta compared to the DM group or the control group $(\mathrm{p}<0.05)$. Conclusion: It can be concluded that a high dose of cathecin isolate from GMB-4 clone green tea $(60 \mathrm{mg} / \mathrm{kgBB})$ may trigger the proliferation and maturation of EPCs in rats with type $2 \mathrm{DM}$ in an environment with a high level of NO, involving the interaction between SDF-1 $\alpha$ and CXCR4 in the aorta.
\end{abstract}

Keywords: aorta; catechins; endothelial progenitor cells; hyperglycemia.

\section{INTRODUCTION}

Type 2 diabetes mellitus is a chronic multi-factorial metabolic disease caused by a complex interaction between various environmental and genetic factors (G. P. Fadini et al., 2006). Type 2 diabetes mellitus is a cause of morbidity and mortality, especially due to vascular complications that lead to retinopathy, nephropathy, ischemic heart disease and peripheral vasculopathy (Tang, Fang and Zhou, 2013).

A severe decrease in the population of circulatory precursor cells (CD34+ dan CD133+) with the ability for them to differentiate into mature endothelial cells and to play a role in vascular homeostasis and neoangiogenesis has been characterised in diabetes mellitus (Gian Paolo Fadini, Saverio Sartore, 2007). In order to maintain vascular homeostasis, vascular endothelial cells will produce several biofactors (Vanhoutte, 2003). During endothelial injury, there is an increase in endothelial cell division to trigger regeneration in the damaged endothelial cells (Brandes, Fleming and Busse, 2005). Endothelial progenitor cell will inhibit the senecence of endothelial cells, preserving endothelial homeostasis, and supporting vascular recovery involved in various diseases, including type 2 diabetes mellitus (Urbich and Dimmeler, 2004).
Stromal cell-derived factor 1 (SDF-1)

belongs to a group of $\alpha$-chemokines that will bind to the CXCR4 transmembrane protein receptor(G. P. Fadini et al., 2006). One of the main physiological functions of SDF1/CXCR4 is to regulate homing and the self-defence system of the stem cells and hematopoietic progenitor cells (Christopherson, 2003). SDF1 also functions to increase the proliferation of hematopoietic progenitor cells, attracting CXCR4-expressing progenitor cells to the bone marrow microenvironment (Liles et al., 2003).

Various plant products have been used as a therapeutic substance, including green tea (Wardhana, Ratnawati and Suyuti, 2013). The Tea and Quinine Research Association in Gambung have developed a variety of green teas with higher catechins compared to other tea plants, called GMB4 clone (Mawarti, Ratnawati and Lyrawati, 2012). Previous studies have shown that the catechins isolated from GMB4 clone green tea are metabolically beneficial due to the fact that they inhibit insulin resistance in visceral adipose cells and adipose tissues (Susanti, Rudijanto and Ratnawati, 2012) and the decrease of C/EBP $\alpha$ expression in cultured mice pre-adiposites (Mawarti, Ratnawati and Lyrawati, 2012). On the other hand, in the in-vivo studies, the catechins isolated from GMB4 clone green tea were shown to be able to reduce eNOS, to 
increase the expression of PI3K and to decrease the activity of p38 MAPK in rats with high fat diet (Wardhana, Ratnawati and Suyuti, 2013).

To our knowledge, there have been no studies conducted to identify the benefit of catechins isolated from GMB4 clone green tea towards the endothelial progenitor cells in type 2 diabetes. Therefore, in this study, we have evaluated the role of catechins isolated from GMB4 clone green tea on the dynamics of endothelial progenitor cells in type 2 diabetes mellitus.

\section{MATERIALS AND METHODS}

\section{Subjects}

Twenty five 3-4 months old male Wistar rats were divided into five groups, namely the control group, type 2 diabetes mellitus group, and three groups of rats with type 2 diabetes mellitus treated with catechins isolated from GMB4 clone green tea in 20; 40; and $60 \mathrm{mg} / \mathrm{kgBW}$ doses respectively, every day for 6 weeks.

We had to induce type 2 diabetes mellitus in rats. Before being treated, the rats underwent an adaptation phase for 2 weeks with a standard diet. The induction of type 2 diabetes mellitus started with a hypercholesterol diet for 45 days, followed by an intraperitoneal injection of $30 \mathrm{mg} / \mathrm{kgBW}$ streptozotocin. Three days after the induction of streptozotocin, their blood glucose was examined after a 6 hour fast. If the blood glucose level reached above $250 \mathrm{mg} / \mathrm{dl}$, the rat was categorised as having hyperglycemia.

\section{Administration of catechins isolates}

The catechins isolated from GMB-4 clone green tea were administered via an NGT to the animals in the doses described above, with a maximum of $10 \mathrm{ml} / \mathrm{day}$. Before touching the animals, the NGT must first be filled with an isolate dose with no air bubble, as that would generate pain and cause the rat to struggle. The NGT was equipped with a round tip needle to reduce the possibility of tracheal injection. The isolates was administered in 20; 40; and $60 \mathrm{mg} / \mathrm{kgBW}$ doses daily for 6 weeks.

\section{Euthanasia}

After 6 weeks of treatment with catechins isolated from the GMB-4 Clone Green Tea, the animals were then dissected as follows: the animals were locally anesthesised with ether followed with a dissection of the abdominal region and diaphragm. Five $\mathrm{ml}$ blood samples were then collected from the animal's heart using a syringe. The blood samples collected were then examined. The deceased animals were buried in a location provided by the Physiology Laboratorium of Brawijaya University.

\section{EPCs count analysis}

The EPCs count analysis was performed using flow cytometry. The EPCs were characterised by CD34+ and CD133+cells.

\section{Nitrite oxide measurement}

The nitrite oxide was measured using the colorimetric technique. The analysis procedure was performed according to the detailed instructions provided in the kit.

\section{SDF1- $\alpha$ level and concentration measurement}

The SDF1- $\alpha$ serum concentration measurement was performed using a SDF1- $\alpha$ ELISA kit. The analysis procedure was performed according to the detailed instructions provided in the kit. The measurement of SDF1- $\alpha$ expression in the aorta was performed using the immunohistochemistry technique.

\section{Measurement of CXCR-4 expression}

The measurement of CXCR-4 expression in the aorta was performed using the immunohistochemistry technique (Schmidt -Lucke et al., 2005) (Leone et al., 2009).

\section{Ethics}

The care of the animal subjects and the experimental procedure was approved by the Research Ethics Committee of Brawijaya University Medical School, Malang, East Java, Indonesia.

\section{Statistical analysis}

The data was presented in means $\pm \mathrm{SD}$ and the difference between treatment groups was analysed using a one-way ANOVA test in SPSS 16.0 software. The Post-Hoc test performed in the ANOVA test generated a significant difference. $\mathrm{P}$ value of $<0.05$ which was deemed statistically significant. 


\section{RESULTS}

The CD34+ count was lower in the diabetes mellitus group compared to the control group $(\mathrm{P}<0.05)$. Of the three catechin doses, only the highest dose was able to significantly increase the CD34+ count compared to the diabetes mellitus group $(\mathrm{P}<$ 0.05). This increased CD34+ count reached a level comparable to that of the control group $(\mathrm{P}>0.05)$, as seen in Figure 1.

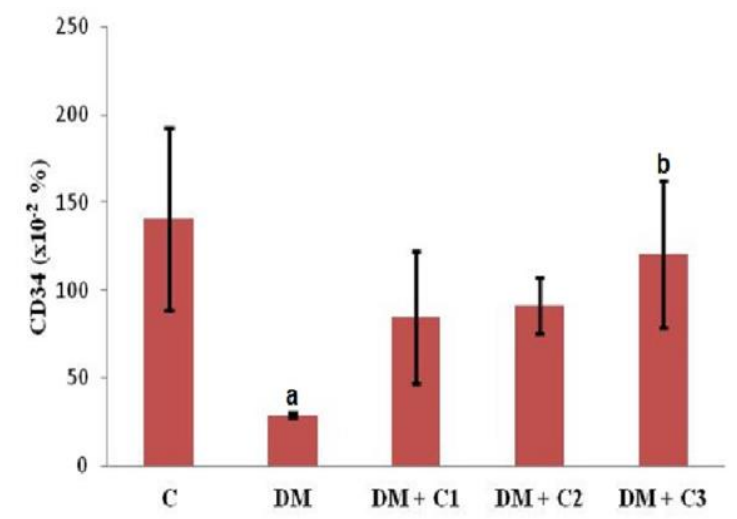

Figure 1. The $\mathrm{CD}_{3} 4^{+}$count in each experimental groups. Values are presented as mean \pm $\mathrm{SD} ;{ }^{\mathrm{a}} \mathrm{P}<0.05$ in comparison with control (C) group; ${ }^{\mathrm{b}} \mathrm{P}<0.05$ in comparison with diabetes mellitus $(\mathrm{DM})$ group. $\mathrm{DM}+\mathrm{C} 1$ : diabetes mellitus group received first dose of catechin; DM + C2: diabetes mellitus group received second dose of catechin; $\mathrm{DM}+\mathrm{C}$ 3: diabetes mellitus group received third dose of catechin; \%: percentage.

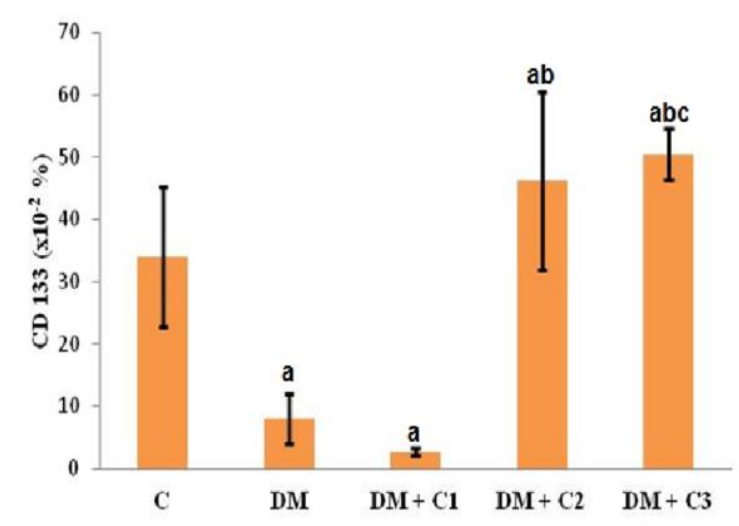

Figure 2. The $\mathrm{CD} 133^{+}$count in each experimental groups. Values are presented as mean \pm $\mathrm{SD} ;{ }^{\mathrm{a}} \mathrm{P}<0.05$ in comparison with control (C) group; ${ }^{\mathrm{b}} \mathrm{P}<0.05$ in comparison with diabetes mellitus (DM) group; ${ }^{\mathrm{c}} \mathrm{P}<0.05$ in comparison with first dose catechin administered $(\mathrm{DM}+\mathrm{C} 1)$ group; $\mathrm{DM}+\mathrm{C} 2$ : diabetes mellitus group received second dose of catechin; DM + C3: diabetes mellitus group received third dose of catechin; \%: percentage
The CD133+ count was lower in the diabetes mellitus group compared to the control group $(\mathrm{P}<0.05)$. Of all three catechin doses, only the second highest dose was able to significantly increase the CD133+ count

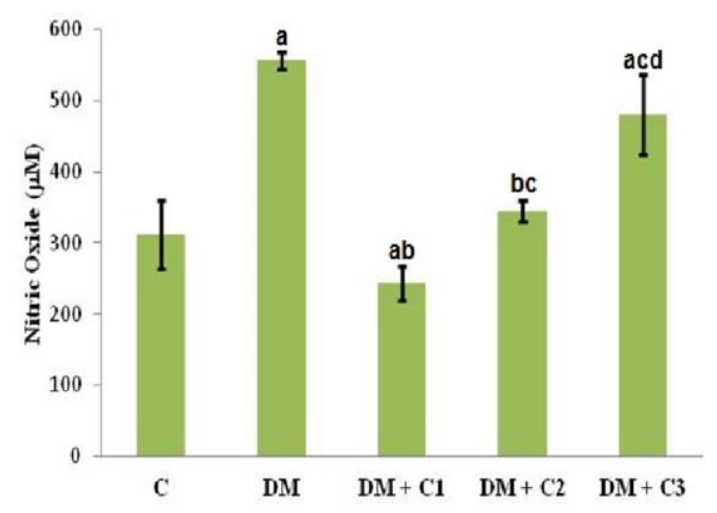

Figure 3. The serum NO level in each experimental groups. Values are presented as mean $\pm \mathrm{SD}$; ${ }^{\mathrm{a}} \mathrm{P}<0.05$ in comparison with control (C) group; ${ }^{\mathbf{b}} \mathrm{P}<0.05$ in comparison with diabetes mellitus (DM) group; ${ }^{\mathrm{c}} \mathrm{P}<0.05$ in comparison with first dose catechin administered (DM $+\mathrm{C} 1)$ group; ${ }^{\mathrm{d}} \mathrm{P}<0.05$ in comparison with second dose catechin administered (DM + C2) group. $\mathrm{DM}+\mathrm{C} 3$ : diabetes mellitus group received third dose of catechin; $\mu \mathrm{M}$ : micromolar.

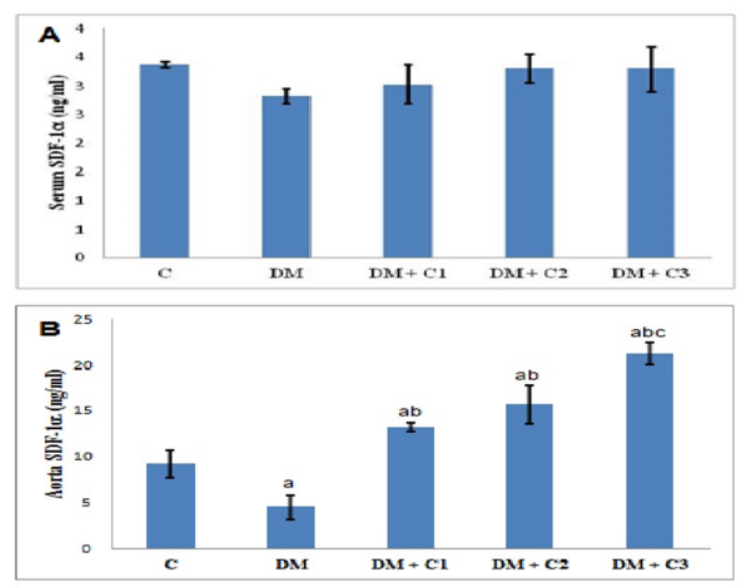

Figure 4. The serum SDF- $1 \alpha$ level (A) and aorta expression of SDF-1 $\alpha$ (B) in each experimental groups. Values are presented as mean $\pm \mathrm{SD}$; ${ }^{\mathrm{a}} \mathrm{P}<0.05$ in comparison with control (C) group; ${ }^{\mathbf{b}} \mathrm{P}<0.05$ in comparison with diabetes mellitus (DM) group; ${ }^{\mathbf{c}} \mathrm{P}<0.05$ in comparison with first dose catechin administered (DM $+\mathrm{C} 1)$ group; $\mathrm{DM}+\mathrm{C} 2$ : diabetes mellitus group received second dose of catechin; DM + C3: diabetes mellitus group received third dose of catechin; SDF-1 $\alpha$ : stromal derived factor-1 $\alpha$; ng/ml: nanogram/mililiter. 


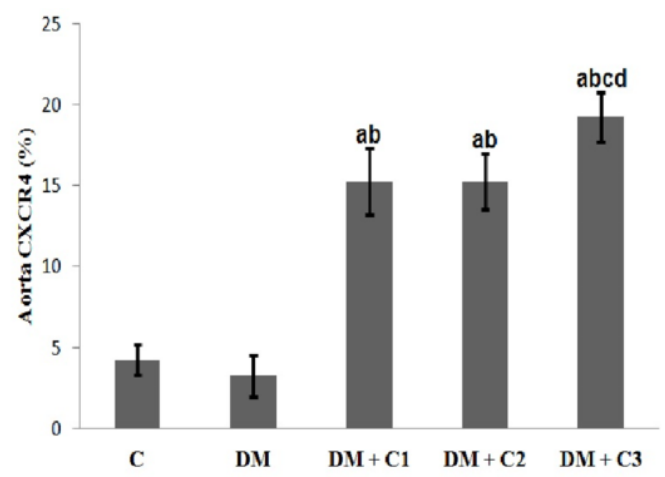

Figure 5. The aorta expression of CXCR4 in each experimental groups. Values are presented as mean $\pm \mathrm{SD} ;{ }^{\mathrm{a}} \mathrm{P}<0.05$ in comparison with control (C) group; ${ }^{\mathbf{b}} \mathrm{P}<0.05$ in comparison with diabetes mellitus (DM) group; ${ }^{\mathbf{c}} \mathrm{P}<0.05$ in comparison with first dose catechin administered (DM $+\mathrm{C} 1)$ group; ${ }^{\mathrm{d}} \mathrm{P}<0.05$ in comparison with second dose catechin administered (DM $+\mathrm{C} 2)$ group; $\mathrm{DM}+\mathrm{C} 3$ : diabetes mellitus group received third dose of catechin; \%: percentage.

compare to the diabetes mellitus group ( $\mathrm{P}<$ 0.05 ), and this increased CD133+ count was comparable to that of the control group (P > $0.05)$. In addition, there was no difference in the CD133+ count between both highest doses $(\mathrm{P}>0.05)$ (Figure 2).

The serum level of NO was significantly higher in the diabetes mellitus compared to the control group $(\mathrm{P}<0.05)$. Of all three catechin doses, only the first and second doses were able to significantly reduce the NO level compared to the diabetes mellitus group $(\mathrm{P}<0.05)$. However, only the rats administered with second doses have NO levels comparable to that of the control group $(\mathrm{P}>0.05)$, as seen in Figure 3.

For the serum SDF- $1 \alpha$ concentration, there was no significant difference between all of the treatment groups $(\mathrm{P}>0.05)$ (Figure 4A). Meanwhile, the expression of SDF- $1 \alpha$ in the aorta was significantly lower in the diabetes mellitus group compared to the control group $(\mathrm{P}<0.05)$. All three doses of catechin were able to significantly increase the expression of SDF- $1 \alpha$ in the aorta compared to the rats in the diabetes mellitus group or the control group $(\mathrm{P}<0.05)$ (Figure 4B).

Figure 5 presents the CXCR4 level in the aorta between groups. There was no significant difference in terms of the expression of CXCR4 in the aorta between the diabetes mellitus group and the control group
$(\mathrm{P}>0.05)$. All three doses of catechin seemed able to significantly increase the expression of CXCR4 in the aorta compared to the rats in the diabetes mellitus group or the control group ( $\mathrm{P}$ $<0.05)$. There was no significant difference for CXCR4 expression in the aorta between the first and second doses of catechin $(\mathrm{P}>$ $0.05)$.

\section{DISCUSSION}

To fight against endothelial cell injury due to diabetes, several recovery mechanisms will ensue. Traditionally, the permanent proliferation of cells in the vascular tissue is responsible for microvascular recovery. To date, there has been numerous evidence that EPCs play a role in the recovery and homeostasis of endothelial cells. EPCs are produced in the bone marrow, mobilised in the circulation and recruited in the location of injury. In the location of injury, EPCs will differentiate into endothelial cells to replace the damaged endothelial cells or to provide paracrine support to the vascular cells. eNOS plays a role in the differentiation of EPCs and NO from the eNOS that are able to regulate endothelial recovery and reendothelialisation through the differentiation of EPCs. In the current study, the serum NO level was found to be significantly higher in the diabetes mellitus group compared to the control group $(\mathrm{P}<0.05)$. This indicates that the increase of $\mathrm{NO}$ is a compensational mechanism aimed to regulate endothelial recovery and reendothelialisation through the differentiation of EPC into endothelial cells. In this study, the CD34+ and CD133+ count was found to be lower in the diabetes mellitus group compared to the control group $(\mathrm{P}<0.05)$. This indicates that despite the existence of a homeostasis mechanism through the increase of the NO level, hyperglycemia is still able to trigger a decrease in the CD34+ and CD133+ cell population. Various studies have mentioned that diabetic patients experienced a decrease in EPCs as well as the functional disruption of EPCs, including a decrease in proliferation, adhesion, migration and incorporation (Boos, Lip and Blann, 2006) (Gian Paolo Fadini et al., 2006) (Gallagher et al., 2007) (Peristiowati, Indasah and Ratnawati, 2015). This study is consistent with previous studies in finding a reduced population, migration and proliferation of EPCs in rats with type 2 
diabetes mellitus (Tikhonenko et al., 2013) (Chen et al., 2010).

The increased SDF-1 $\alpha$ was able to induce chemotaxis of EPCs via the HIF pathway by binding with CXCR4. The defect of EPCs mobilisation in rats with diabetes was associated with the insufficiency of SDF- $1 \alpha$ release (Gill et al., 2001) (Chen et al., 2010) (Gallagher et al., 2007). In the current study, there was no significant difference in terms of serum SDF1- $\alpha$ concentration between all of the treatment groups $(\mathrm{P}>0.05)$. This indicates that there was no insufficiency in SDF- $1 \alpha$ release. However, the expression of SDF- $1 \alpha$ in the aorta was significantly lower in the diabetes mellitus group compared to the control group $(\mathrm{P}<0.05)$. In addition, there was also no significant difference in terms of the expression of CXCR4 in the aorta between diabetes mellitus group and the control group $(\mathrm{P}>0.05)$. This indicates that hyperglycemia reduces the bond between SDF-1 $\alpha$ and CXCR4 in the aorta. Thus, in the rat model of type 2 diabetes mellitus, hyperglycemia will trigger a decrease in $\mathrm{CD} 34^{+}$and $\mathrm{CD} 133^{+}$cell population as well as its homing capacity, despite the existence of a compensational mechanism in the form of increased NO level.

In previous studies, catechins were found to be able to accelerate endothelial progenitor cell proliferation along with an increased dose and duration of incubation (Boos, Lip and Blann, 2006). In the current study, the highest dose was found to be able to significantly increase CD $34^{+}$count compared to the rats in the diabetes mellitus group ( $\mathrm{P}<$ $0.05)$, and this increase is comparable to that of the control group $(\mathrm{P}>0.05)$. Meanwhile, the maturation function of EPCs was found to be significantly increased in the groups treated with the second and third doses compared to the diabetes mellitus group $(\mathrm{P}<0.05)$, and there were no significant difference in terms of CD133+ count between the two highest doses $(\mathrm{P}>0.05)$. However, all three doses of cathecin were able to significantly increase the expression of SDF1- $\alpha$ and CXCR4 in the aorta compared to the diabetes mellitus or control group $(\mathrm{P}<0.05)$. This indicates that all of the doses of catechin were able to increase the bond between SDF- $1 \alpha$ and CXCR4, despite the fact that EPCs proliferation and endothelial maturation only optimally occurs in the highest dose. When associated with the NO level, it was found that the group treated with the third dose had a very high level of NO, therefore, it can be concluded that the recovery of the proliferation and maturation of EPCs in rats with type 2 diabetes mellitus occur optimally in the highest dose and in environments with high NO levels.

\section{CONCLUSIONS}

It can be concluded that a high dose of cathecin isolate from GMB-4 clone green tea $(60 \mathrm{mg} / \mathrm{kgBB})$ may trigger the proliferation and maturation of EPCs in rats with type 2 diabetes mellitus in an environment with a high level of $\mathrm{NO}$, involving the interaction between SDF- $1 \alpha$ and CXCR 4 in the aorta.

\section{REFERENCES}

Boos, C. J., Lip, G. Y. H. and Blann, A. D. (2006) 'Circulating Endothelial Cells in Cardiovascular Disease', Journal of the American College of Cardiology, 48(8), pp. 1538-1547.

Brandes, R. P., Fleming, I. and Busse, R. (2005) 'Endothelial aging', Cardiovascular Research, 66(2), pp. 286-294. doi: 10.1016/j.cardiores.2004.12.027.

Chen, L. et al. (2010) 'CXCR4 gene transfer contributes to in vivo reendothelialization capacity of endothelial progenitor cells', Cardiovascular Research, 88(3), pp. 462-470.

Christopherson, K. W. (2003) 'Cell surface peptidase CD26/DPPIV mediates GCSF mobilization of mouse progenitor cells', Blood, 101(>12), pp. 46804686.

Fadini, G. P. et al. (2006) 'Diabetes impairs progenitor cell mobilisation after hindlimb ischaemia-reperfusion injury in rats', Diabetologia, 49(12), pp. 3075-3084.

Fadini, G. P. et al. (2006) 'Number and function of endothelial progenitor cells as a marker of severity for diabetic vasculopathy, Arteriosclerosis, Thrombosis, and Vascular Biology, 26(9), pp. 2140-2146.

Gallagher, K. A. et al. (2007) 'Diabetic impairments in NO-mediated endothelial progenitor cell mobilization and homing are reversed 
by hyperoxia and SDF-1??', Journal of Clinical Investigation, 117(5), pp. 1249-1259.

Gian Paolo Fadini, Saverio Sartore, C. A. and A. A. (2007) 'Significance of Endothelial Progenitor Cells', Diabetes Care, 30(5), pp. 1305-1313.

Gill, M. et al. (2001) 'Vascular Trauma Induces Rapid but Transient Mobilization of VEGFR2+AC133+ Endothelial Precursor Cells', Circulation Research, 88(2), pp. 167174.

Leone, A. M. et al. (2009) 'From bone marrow to the arterial wall: The ongoing tale of endothelial progenitor cells', European Heart Journal, 30(8), pp. 890-899.

Liles, W. C. et al. (2003) 'Brief report Mobilization of hematopoietic progenitor cells in healthy volunteers by AMD3100 , a CXCR4 antagonist', October, 102(8), pp. 2728-2730.

Mawarti, H., Ratnawati, R. and Lyrawati, D. (2012) 'Epigallocatechin Gallate Menghambat Resistensi Insulin pada Tikus dengan Diet Tinggi Lemak Inhibitory Effect of Epigallocatechin Gallate on Insulin Resistance in Rat with High Fat Diet', Jurnal Kedokteran Brawijaya, 27(1), pp. 4350.

Peristiowati, Y., Indasah, I. and Ratnawati, R. (2015) 'The effects of catechin isolated from green tea GMB-4 on $\mathrm{NADPH}$ and nitric oxide levels in endothelial cells exposed to high glucose.', Journal of intercultural ethnopharmacology, 4(2), pp. 114-7. doi: $10.5455 /$ jice.20141224104135.

Schmidt-Lucke, C. et al. (2005) 'Reduced number of circulating endothelial progenitor cells predicts future cardiovascular events: Proof of concept for the clinical importance of endogenous vascular repair', Circulation, 111(22), pp. 2981-2987.

Susanti, E., Rudijanto, A. and Ratnawati, R. (2012) 'Catechins inhibit atherosclerosis in male rats on a high fat diet', 31(2), pp. 81-87.

Tang, Z.-H., Fang, Z. and Zhou, L. (2013) 'Human genetics of diabetic vascular complications', Journal of Genetics, 92(3), pp. 677-694.

Tikhonenko, M. et al. (2013) 'N-3 Polyunsaturated Fatty Acids Prevent Diabetic Retinopathy by Inhibition of Retinal Vascular Damage and Enhanced Endothelial Progenitor Cell Reparative Function', PLOS ONE, 8(1), pp. 1-10. doi: 10.1371/journal.pone.0055177.

Urbich, C. and Dimmeler, S. (2004) 'Endothelial progenitor cells: Characterization and role in vascular biology', Circulation Research, 95(4), pp. 343-353. doi: 10.1161/01.RES.0000137877.89448.7 8.

Vanhoutte, P. M. (2003) 'Endothelial control of vasomotor function: from health to coronary disease.', Circulation journal: official journal of the Japanese Circulation Society, 67(July), pp. 572-575.

Wardhana, A. W., Ratnawati, R. and Suyuti, H. (2013) 'Isolat EGCG Teh Hijau Klon GMB4 Menurunkan Ekspresi Protein Faktor Transkripsi C / EBP $\alpha$ dan Kadar Leptin pada Kultur Sel Preadiposit Visceral Tikus', Jurnal Kedokteran Brawijaya, 27(4), pp. 212-216. 